\section{HARMONI SOSIAL}

Jurnal Pendidikan IPS
Harmoni Sosial: Jurnal Pendidikan IPS

Volume 3, No 2, September 2016 (177-187)

Online: http://journal.uny.ac.id/index.php/hsjpi

\title{
EVALUASI KINERJA GURU IPS SMP BERDASARKAN STANDAR KOMPETENSI GURU DI KABUPATEN KEBUMEN
}

\author{
Ria Widarsih1, Nahiyah Jaidi Faraz2 \\ 1SMK Negeri 1 Ambal Kebumen 2Universitas Negeri Yogyakarta \\ riawidarsih@gmail.com,nahiyah@uny.ac.id
}

\begin{abstract}
Abstrak
Penelitian ini bertujuan untuk mengetahui kompetensi pedagogik, kompetensi kepribadian, kompetensi sosial, dan kompetensi profesional guru IPS SMP di Kabupaten Kebumen berdasarkan penilaian dari asesor dan penilaian diri sendiri. Jenis penelitian ini termasuk penelitian evaluatif. Model evaluasi yang digunakan adalah model evaluasi benchmarking (bangku ukur). Pendekatan penelitian yang digunakan adalah kuantitatif deskriptif. Populasi penelitian adalah seluruh guru IPS SMP di kabupaten Kebumen. Pemilihan sampel guru IPS dilakukan dengan propotional random sampling sebanyak 134 guru. Teknik pengumpulan data menggunakan angket. Teknik analisis data menggunakan analisis statistik deskriptif dengan persentase. Hasil penelitian membuktikan bahwa: (1) kompetensi pedagogik guru IPS SMP di Kabupaten Kebumen dalam kategori baik dengan persentase sebesar 88,00\%; (2) kompetensi kepribadian guru IPS SMP di Kabupaten Kebumen dalam kategori amat baik dengan persentase sebesar 93,09\%; (3) kompetensi sosial guru IPS SMP di Kabupaten Kebumen dalam kategori baik dengan persentase sebesar 88,65\%; (4) kompetensi profesional guru IPS SMP di Kabupaten Kebumen dalam kategori baik dengan persentase sebesar $79,53 \%$.
\end{abstract}

Kata Kunci: kompetensi pedagogik, kompetensi kepribadian, kompetensi sosial, dan kompetensi profesional.

\section{EVALUATION OF PERFORMANCE OF SOCIAL SCIENCE TEACHERS AT JUNIOR HIGH SCHOOLS BASED ON TEACHER'S STANDARD COMPETENCE IN KEBUMEN REGENCY}

\author{
Ria Widarsih1, Nahiyah Jaidi Faraz2 \\ 1SMK Negeri 1 Ambal Kebumen 2Universitas Negeri Yogyakarta \\ riawidarsih@gmail.com,nahiyah@uny.ac.id
}

\begin{abstract}
The research objectives were to reveal pedagogical competence, personality competence, social competence, and professional competence of social science teachers at junior high schools in Kebumen Regency based on the assessor's assessment and self assessment. This was a evaluation research using bechmarking evaluation model with descriptive kuantitatif. The research population was all social science teachers at junior high schools in Kebumen Regency. The sample, consisting of 134 teachers, was selected using the proportional random sampling technique. The data were collected through questionnaires. They were analyzed using descriptive statistics with percentage. The research finding proved that: (1) pedagogical competence of social science teachers at junior high schools in Kebumen Regency is in the good category with the percentage $88.00 \%$; (2) personality competence of social science teachers at junior high schools in Kebumen Regency is in the very good category with the percentage 93.09\%; (3) social competence of social science teachers at junior high schools in Kebumen Regency is in the good
\end{abstract}


category with the percentage each of $88.65 \%$; (4) professional competence of social science teachers at junior high schools in Kebumen Regency is in the good category with the percentage 79.53\%.

Keywords: pedagogical competence, personality competence, social competence, and professional competence.

\section{Pendahuluan}

Salah satu faktor utama dalam menilai keberhasilan pembangunan sebuah negara adalah pengembangansistempendidikan.Pengembangan sistem pendidikan ini dipengaruhi oleh berbagai faktor, salah satu faktor yang sangat penting adalah proses belajar mengajar (pendidikan). Hal ini sependapat dengan Suryarahman (2014, p.2) yang menyatakan bahwa upaya untuk menciptakan dan meningkatkan sumber daya manusia dapat ditempuh melalui pendidikan. Salah satu sosok penting dalam dunia pendidikan adalah guru. Guru disebut agent of change karena memiliki posisi strategis dalam menentukan nasib bangsa dimasa yang akan datang. Guru berada di garda terdepan dalam menciptakan kualitas sumber daya manusia. Guru menurut Hamalik (2008, p.118) adalah seseorang yang secara sadar bertanggung jawab dalam mendidik, mengajar, dan membimbing peserta didik baik di sekolah maupun di luar sekolah agar menjadi manusia yang berguna bagi nusa dan bangsa.

Rachmawati \& Daryanto (2013, p.101) berpendapat bahwa pekerjaan guru pada kultur masyarakat Indonesia sampai saat ini masih cukup tertutup, bahkan atasan guru seperti kepala sekolah dan pengawas sekalipun, tidak mudah untuk mendapatkan data dan mengamati realitas keseharian kinerja guru dihadapan peserta didik. Memang kunjungan kelas oleh kepala sekolah atau pengawas, tidak mungkin ditolak guru. Akan tetapi, tidak jarang terjadi guru berusaha menampakkan kinerja terbaiknya baik pada aspek perencanaan maupun pelaksanaan pembelajaran hanya pada saat kunjungan kepala sekolah dan pengawas. Selanjutnya, guru akan kembali bekerja seperti sediakala, kadang tanpa persiapan yang matang serta tanpa semangat dan antusiasme yang tinggi.

Priansa (2014, p.354) yang menyatakan bahwa hasil penilaian kinerja guru dimanfaatkan dalam penyusunan profil kinerja guru sebagai input dalam penyusunan program PKB dan dasar dalam PAK. Hal ini tidak jarang membuat penilai menilai dalam kategori baik dan tidak begitu memperhatikan kondisi atau kenyataan yang ada.

Tidak semua asesor memiliki latar belakang pendidikan yang sama dengan guru yang dinilai. Latar belakang pendidikan yang tidak sama pasti akan menimbulkan bias dalam penilaian. Salah satunya terkait dengan kompetensi profesional guru tentang penguasaan materi. Seseorang yang tidak memiliki latar belakang pendidikan IPS pasti tidak terlalu menguasai materi IPS. Lalu bagaimana jika mereka melakukan penilaian pada kinerja guru IPS? Tentu hasilnya masih perlu dipertanyakan.

Selain permasalahan tersebut, guru IPS SMP di Kabupaten Kebumen tidak memiliki kualifikasi pendidikan guru IPS. Guru IPS SMP memiliki latar belakang pendidikan dari salah satu disiplin ilmu dalam IPS. Latar belakang pendidikan guru akan mempengaruhi proses pembelajaran. Misalnya, guru dengan latar belakang pendidikan sebagai sarjana pendidikan ekonomi tentu akan lebih menguasai materi tentang ekonomi dari pada sejarah, geografi, dan sosiologi. Oleh karena itu, ketika pembelajaran berlangsung guru akan lebih sering mengaitkan materi dengan pendekatan ekonomi.

Menurut Harriyanti (2000, p.45), rendahnya kinerja guru dapat dilihat dari fenomena-fenomena di lapangan antara lain masih ada sebagian guru kurang mampu membuat perencanaan pengajaran dengan baik, kurang terampil menggunakan media pembelajaran, kurang dapat mengaktifkan siswa dalam belajar, kurang mampu menentukan metode pengajaran yang tepat, dan kurang menguasai materi yang diajarkan.

Penelitian dari Kelly A. Parkes mengenai performance assessment: lessons from performers menunjukkan bahwa penilaian kinerja yang baik akan memberikan umpan balik bagi peserta didik salah satunya pada hasil belajar peserta didik. Selain itu, penilaian kinerja yang baik juga akan memberikan efek yang positif pada kinerja rekan sejawat. Berdasarkan penelitian ini, penilaian 
kinerja guru memberikan manfaat yang sangat besar.

Sementara itu, berdasarkan penelitian dari Muhammad Nursa'ban, Suparmini, \& Sriadi Setyowati yang berjudul evaluasi kompetensi pedagogik guru geografi SMA di Kabupaten Bantul menunjukkan bahwa (1) kompetensi pedagogik guru geografi SMA di Kabupaten Bantul berdasarkan rata-rata penilaian kepala sekolah, guru, dan peserta didik sudah pada kategori baik. (2) Penilaian terhadap kompetensi 5 dan 10 dalam kategori cukup. (3) Penilaian yang dilakukan oleh guru dan kepala sekolah lebih tinggi dibandingkan penilaian oleh peserta didik. Perbedaan penilaian dari berbagai pihak, dapat disebabkan karena adanya bias dalam penilaian kinerja guru.

Berdasarkan beberapa permasalahan yang telah dipaparkan dan karena pada saat penelitian belum ada data tentang kinerja guru IPS SMP di Kabupaten Kebumen untuk tahun pelajaran 2014/ 2015, maka peneliti merasa perlu untuk melakukan evaluasi kinerja guru IPS SMP berdasarkan standar kompetensi guru.

Permendiknas No. 16 tahun 2007 tentang Standar Kualifikasi Akademik dan Kompetensi Guru menyatakan bahwa guru profesional harus memiliki kualifikasi akademik minimum sarjana (S-1) atau diploma empat (D-IV), menguasai kompetensi, memiliki sertifikat pendidik, sehat jasmani dan rohani, serta memiliki kemampuan untuk mewujudkan tujuan pendidikan nasional. Widoyoko (2012, p.201) kinerja guru berkaitan dengan kompetensi guru, tanpa memiliki kompetensi yang baik seorang guru tidak akan mungkin dapat memiliki kinerja yang baik. Sementara itu, Jones dkk (2006, p.3) menyatakan bahwa: "individual's performance could therefore be regarded as the way in which they get tasks (e.g. teaching, marking, assessments) done". Hal ini mengandung makna bahwa kinerja seseorang dapat dianggap karena mereka telah menyelesaikan tugas (mengajar, melakukan penilaian, dan lain-lain).

Yamin \& Maisah (2010: V) berpendapat bahwa kompetensi adalah kemampuan yang dimiliki seseorang sehingga membolehkan ia untuk mengisi suatu peran, kompetensi juga merupakan pengetahuan dan keterampilan yang menjadi kunci untuk menghasilkan output dari suatu pelatihan dan pengembangan peran mereka.
Berdasarkan pendapat tersebut maka kompetensi guru merupakan modal utama bagi guru untuk melaksanakan profesinya, karena kompetensi yang tinggi akan menghasilkan output yang baik. Output disini bisa diartikan sebagai hasil belajar dan prestasi peserta didik.

Kompetensi guru sebagai agen pembelajaran pada jenjang pendidikan dasar dan menengah serta pendidikan anak usia dini meliputi: kompetensi pedagogik, kompetensi kepribadian, kompetensi profesional, dan kompetensi sosial. Kompetensi pedagogik terkait dengan kemampuan guru dalam memahami dan mengaplikasikan ilmu-ilmu pendidikan pada peserta didik. Kompetensi profesional terkait dengan kemampuan guru dalam menguasai mata pelajaran yang diampu secara luas dan mendalam termasuk pada ilmu pengetahuan pendukungnya. Kompetensi kepribadian terkait dengan sosok pribadi guru yang mengacu pada individu sebagai panutan bagi peserta didik maupun masyarakat. Kompetensi sosial adalah kompetensi guru yang berkaitan dengan kemampuan guru untuk bermasyarakat.

Keefektifan pelaksanaan peran guru sebagai agen pembelajaran tergantung pada tingkat kompetensi guru yang bersangkutan. Keempat kompetensi tersebut diformulasikan dan diintegrasikan menjadi standar kompetensi guru. Guru yang profesional dapat dilihat dari seberapa jauh kesesuaian antara tindakan dan sikap terhadap standar kompetensi guru. Untuk mengetahui tingkat kesesuaian ini, maka perlu dilakukan evaluasi terhadap kinerja guru.

Evaluasi guru memungkinkan bagi guru yang memiliki kinerja dibawah standar minimal, bisa melakukan refleksi dan memperbaiki kinerjanya. Nolan \& Hoover (2011, p.7) mengemukakan pendapat bahwa "evaluation provider assurance that every teacher in the system will be performing at some minimal level of competence". Pendapat tersebut mengandung makna bahwa evaluasi akan memberikan jaminan bahwa setiap guru setidaknya akan memiliki kinerja sesuai dengan standar minimal kompetensi. Standar kompetensi guru di Indonesia diatur dalam Permendiknas Nomor 16 Tahun 2007 tentang Standar Kualifikasi Akademik dan Kompetensi Guru.

Nawawi (2006, p.73) berpendapat bahwa evaluasi kinerja adalah suatu kegiatan mengukur/ 
menilai pelaksanaan pekerjaan untuk menetapkan sukses atau gagalnya seorang pekerja dalam melaksanakan tugas dan tanggung jawab dibidang kerjanya masing-masing. Priatna \& Tito 2013, p.2) menyatakan bahwa unsur-unsur yang dipertimbangkan dalam evaluasi kinerja guru adalah kompetensi guru.

Sementara itu, evaluasi diri menurut Priansa (2014, p.379) adalah metode penilaian pribadi yang digunakan untuk pengembangan diri. Apabila guru menilai dirinya sendiri, maka perilaku defensif cenderung tidak akan terjadi, sehingga upaya untuk perbaikan cenderung dapat dilakukan. Evaluasi diri tidak hanya ditujukan untuk mengukur ketercapaian, tetapi juga untuk mendiagnostik kelemahan dan kelebihan diri, serta meningkatkan diri.

Hasil penelitian ini secara praktis diharapkan dapat bermanfaat bagi pihak-pihak yang terkait, yaitu: pemerintah Daerah Kabupaten Kebumen sebagai dasar pembinaan SDM guru. Selain itu, bagi SMP diharapkan dapat menjadi bahan referensi dalam peningkatan kinerja guru dalam proses pembelajaran IPS dan bagi guru IPS SMP diharapkan dapat dijadikan refleksi apakah kompetensi guru yang dimiliki sudah sesuai dengan Permendiknas Nomor 16 Tahun 2007 tentang Standar Kualifikasi Akademik dan Kompetensi Guru atau belum. Sementara itu, secara teoritis hasil penelitian ini diharapkan dapat dijadikan referensi dan dasar pertimbangan untuk penentuan kebijakan dalam peningkatan kinerja guru sesuai dengan standar kompetensi guru.

\section{Metode Penelitian}

Jenis dan Desain Penelitian

Penelitian ini merupakan jenis penelitian evaluatif. Model evaluasi yang digunakan adalah evaluasi benchmarking (bangku ukur), hasil penelitian akan dibandingkan dengan standar kompetensi guru yang berlaku di Indonesia. Desain penelitian yang digunakan adalah kuantitatif deskriptif.

Waktu dan Tempat Penelitian

Penelitian ini dilaksanakan pada bulan April - Juni 2015 pada SMP di Kabupaten Kebumen.

\section{Definisi Operasional}

Untuk mempermudah dalam penyusunan instrumen dan menginterpretasikan tentang variabel yang akan diukur, maka dalam penelitian ini didefinisikan secara operasional berupa: (1) kompetensi pedagogik guru IPS SMP terkait dengan kemampuan guru dalam mengelola pembelajaran peserta didik, mulai dari perencanaan sampai pada tahap evaluasi, serta mampu mengembangkan potensi yang dimiliki peserta didi; (2) kompetensi kepribadian guru IPS SMP sekurang-kurangnya mencakup tentang kepribadian yang mantap dan stabil, menunjukkan perilaku disiplin, bertindak sesuai dengan norma, bangga sebagai pendidik, dan menjaga kode etik profesi pendidik; (3) kompetensi sosial merupakan kemampuan guru IPS SMP sebagai bagian dari masyarakat yang meliputi kemampuan guru sebagai bagian dari masyarakat untuk berkomunikasi dan bergaul secara efektif dengan peserta didik, sesama pendidik, tenaga kependidikan, atasan, orang tua/wali peserta didik, dan masyarakat; dan (4) kompetensi profesional guru IPS SMP merupakan kemampuan penguasaan materi pembelajaran IPS serta ilmu-ilmu pendukung IPS yang memungkinkan terintegrasikannya konten pembelajaran IPS dengan penggunaan TIK dan membimbing peserta didik memenuhi standar kompetensi yang ditetapkan dalam Standar Nasional Pendidikan.

\section{Populasi dan Sampel Penelitian}

Populasi dalam penelitian ini adalah seluruh guru IPS SMP di Kabupaten Kebumen, yang berjumlah 217 guru. Teknik pengambilan sampel yaitu dengan teknik proportional random sampling. Sampel ditentukan dengan menggunakan tabel penentuan jumlah sampel yang dikembangkan oleh Isaac dan Michael dengan tingkat kesalahan 5\%, sehingga diperoleh sampel sebanyak 134 guru IPS SMP.

Instrumen

Instrumen pengumpulan data yang digunakan adalah angket. Angket yang digunakan dalam penelitian ini merupakan pengembangan instrumen penilaian kinerja guru dari BSNP. Angket ini diisi oleh guru IPS dan asesor dari guru IPS tersebut. 
Teknik Analisis Data

Teknik analisis data yang digunakan dalam penelitian ini adalah statistik deskriptif dengan persentase. Untuk mengkonversi nilai kinerja guru berdasarkan Permennegpan \& Reformasi Birokrasi No. 16 tahun 2009 tentang Jabatan Fungsional Guru dan Angka Kreditnya digunakan rumus sebagai berikut:

$$
\text { Konversi nilai }=\frac{\text { skor } \text { observasi }}{\text { skor harapan }} \times 100
$$

Setelah diketahui konversi nilai kinerja guru, maka langkah selanjutnya adalah mengelompokannya berdasarkan kriteria berikut ini:

Tabel 1. Konversi Nilai Kinerja Guru

\begin{tabular}{|c|c|}
\hline Rentang Nilai & Kategori \\
\hline $91-100$ & Amat baik \\
\hline $76-90$ & Baik \\
\hline $61-75$ & Cukup \\
\hline $51-60$ & Sedang \\
\hline$\leq 50$ & Kurang \\
\hline
\end{tabular}

Sumber: Tutik Rachmawati (2013: 198)

\section{Hasil Penelitian dan Pembahasan}

\section{Evaluasi Kinerja Guru IPS SMP Negeri}

Dari 111 guru yang dinilai oleh asesor diperoleh hasil persentase konversi nilai $\mathrm{PKG}$ IPS SMP Negeri pada kategori amat baik sebanyak 50 guru; baik sebanyak 61 guru; cukup sebanyak 0 guru; sedang sebanyak 0 guru; dan kurang sebanyak 0 guru. Sementara itu, berdasarkan penilaian diri sendiri pada kategori amat baik sebanyak 61 guru; baik sebanyak 40 guru; cukup sebanyak 6 guru; sedang sebanyak 4 guru; dan kurang sebanyak 0 guru. Berikut tabel dan diagram batang konversi nilai kinerja guru IPS SMP Negeri:

Tabel 2. Konversi Nilai Kinerja Guru IPS SMP Negeri

\begin{tabular}{|c|c|c|c|}
\hline $\begin{array}{c}\text { Rentang } \\
\text { Nilai }\end{array}$ & Kategori & Asesor & $\begin{array}{c}\text { Diri } \\
\text { Sendiri }\end{array}$ \\
\hline $91-100$ & Amat baik & 50 & 61 \\
\hline $76-90$ & Baik & 61 & 40 \\
\hline $61-75$ & Cukup & 0 & 6 \\
\hline
\end{tabular}

Tabel 2. Lanjutan

\begin{tabular}{|c|c|c|c|}
\hline $\begin{array}{c}\text { Rentang } \\
\text { Nilai }\end{array}$ & Kategori & Asesor & $\begin{array}{c}\text { Diri } \\
\text { Sendiri }\end{array}$ \\
\hline $51-60$ & Sedang & 0 & 4 \\
\hline$\leq 50$ & Kurang & 0 & 0 \\
\hline
\end{tabular}

Sumber: data responden yang diukur

Tabel 2. menunjukkan bahwa sebagian besar kompetensi guru IPS SMP Negeri di Kabupaten Kebumen berdasarkan penilaian dari asesor dalam kategori baik, sedangkan berdasarkan penilaian diri sendiri dalam kategori amat baik. Data di atas dapat digambarkan dengan diagram batang sebagai berikut:

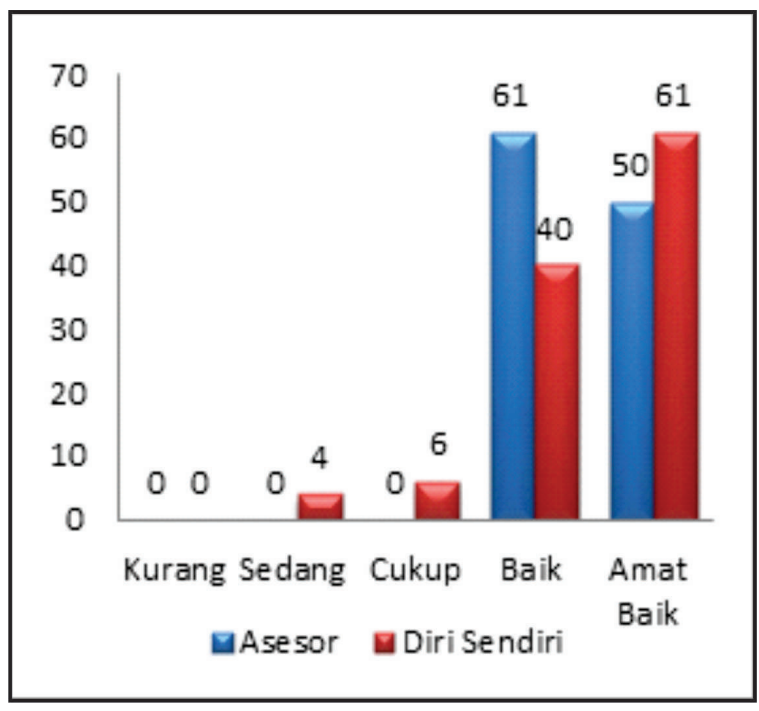

Gambar 1. Diagram Batang Konversi Nilai Kinerja Guru IPS SMP Negeri

Evaluasi Kinerja Guru IPS SMP Swasta

Dari 23 guru yang dinilai oleh asesor diperoleh hasil persentase konversi nilai PKG IPS SMP Swasta pada kategori amat baik sebanyak 2 guru; baik sebanyak 21 guru; cukup sebanyak 0 guru; sedang sebanyak 0 guru; dan kurang sebanyak 0 guru. Sementara itu, berdasarkan penilaian diri sendiri pada kategori amat baik sebanyak 12 guru; baik sebanyak 9 guru; cukup sebanyak 2 guru; sedang sebanyak 0 guru; dan kurang sebanyak 0 guru. Berikut tabel dan diagram batang konversi nilai kinerja guru IPS SMP Swasta: 
Tabel 3. Konversi Nilai Kinerja Guru IPS SMP Swasta

\begin{tabular}{|c|c|c|c|}
\hline $\begin{array}{c}\text { Rentang } \\
\text { Nilai }\end{array}$ & Kategori & Asesor & $\begin{array}{c}\text { Diri } \\
\text { Sendiri }\end{array}$ \\
\hline $91-100$ & Amat baik & 2 & 12 \\
\hline $76-90$ & Baik & 21 & 9 \\
\hline $61-75$ & Cukup & 0 & 2 \\
\hline $51-60$ & Sedang & 0 & 0 \\
\hline$\leq 50$ & Kurang & 0 & 0 \\
\hline
\end{tabular}

Sumber: data responden yang diukur

Tabel 3. menunjukkan bahwa sebagian besar kompetensi guru IPS SMP Swasta di Kabupaten Kebumen berdasarkan penilaian asesor dalam kategori baik, sedangkan berdasarkan penilaian diri sendiri dalam kategori amat baik. Data diatas dapat digambarkan dengan diagram batang sebagai berikut:

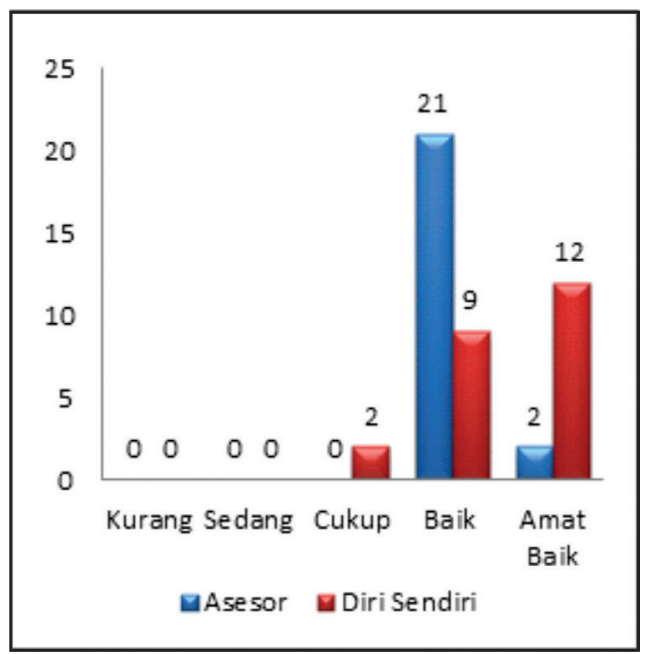

Gambar 2. Diagram Batang Konversi Nilai Kinerja Guru IPS SMP Swasta

Tingkat Ketercapaian Standar Kompetensi Pedagogik Guru IPS SMP

Kompetensi pedagogik terdiri dari 7 indikator dan 43 pernyataan. Berikut ini adalah tabel rekapitulasi penilaian kompetensi pedagogik guru IPS SMP di Kabupaten Kebumen:
Tabel 4. Rekapitulasi Penilaian Kompetensi Pedagogik Guru IPS SMP

\begin{tabular}{|c|c|c|c|c|c|}
\hline \multirow{2}{*}{\multicolumn{2}{|c|}{$\begin{array}{l}\text { Indikator } \\
\text { Asesor }\end{array}$}} & \multicolumn{2}{|c|}{$\begin{array}{c}\text { SMP Negeri } \\
(\%)\end{array}$} & \multicolumn{2}{|c|}{$\begin{array}{c}\text { SMP Swasta } \\
(\%)\end{array}$} \\
\hline & & $\begin{array}{l}\text { Diri } \\
\text { Sen- } \\
\text { diri }\end{array}$ & $\begin{array}{l}\text { Ase- } \\
\text { sor }\end{array}$ & $\begin{array}{l}\text { Diri } \\
\text { Sen- } \\
\text { diri }\end{array}$ & \\
\hline 1 & $\begin{array}{l}\text { Menguasai } \\
\text { karakteris-tik } \\
\text { peserta didik }\end{array}$ & 91,22 & 89,19 & 84,78 & 88,04 \\
\hline 2 & $\begin{array}{l}\text { Menguasai } \\
\text { teori belajar } \\
\text { dan prinsip- } \\
\text { prinsip pembe- } \\
\text { lajaran yang } \\
\text { mendidik }\end{array}$ & 88,74 & 88,74 & 84,78 & 82,61 \\
\hline 3 & $\begin{array}{l}\text { Pengem- } \\
\text { bangan } \\
\text { kurikulum }\end{array}$ & 91,44 & 88,96 & 82,61 & 86,96 \\
\hline 4 & $\begin{array}{l}\text { Kegiatan } \\
\text { pembe-lajaran } \\
\text { yang mendidik }\end{array}$ & 91,44 & 87,39 & 90,22 & 93,48 \\
\hline 5 & $\begin{array}{l}\text { Pengem- } \\
\text { bangan potensi } \\
\text { peserta didik }\end{array}$ & 88,51 & 82,88 & 84,78 & 83,70 \\
\hline 6 & $\begin{array}{l}\text { Komunikasi } \\
\text { dengan peserta } \\
\text { didik }\end{array}$ & 90,54 & 90,77 & 91,30 & 89,13 \\
\hline 7 & $\begin{array}{l}\text { Penilaian dan } \\
\text { evaluasi }\end{array}$ & 87,61 & 89,87 & 85,87 & 86,96 \\
\hline & $\begin{array}{l}\text { Kompetensi } \\
\text { Pedagogik }\end{array}$ & 90,03 & 88,35 & 86,34 & 87,27 \\
\hline
\end{tabular}

Sumber: data responden yang diukur

Berdasarkan Tabel 4. dapat diketahui bahwa berdasarkan penilaian dari asesor untuk kompetensi pedagogik guru IPS SMP Negeri sebesar 90,03\% dan SMP Swasta sebesar 86,34\% dengan kategori masing-masing baik, sedangkan berdasarkan penilaian diri sendiri SMP Negeri sebesar 88,35\% dan SMP Swasta sebesar 87,27\% dengan kategori masing-masing baik. Jika diratarata, maka hasilnya adalah sebesar $88,00 \%$ dan termasuk dalam kategori baik. Hal ini berarti bahwa kinerja guru IPS SMP di Kabupaten Kebumen dilihat dari kompetensi pedagogik 
sudah sesuai dengan Permendiknas No. 16 Tahun 2007 tentang Standar Kualifikasi Akademik dan Kompetensi Guru. Data diatas dapat digambarkan dengan diagram batang sebagai berikut:

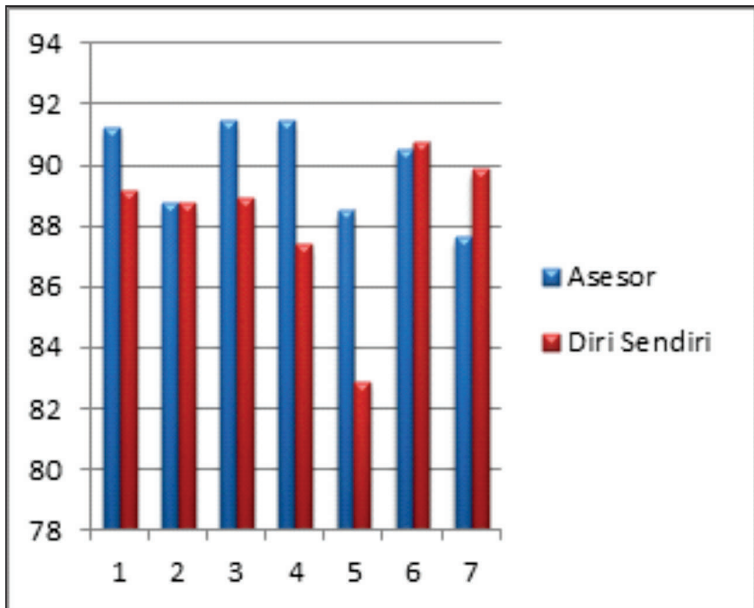

Gambar 3. Rekapitulasi Penilaian Kompetensi Pedagogik Guru IPS SMP Negeri

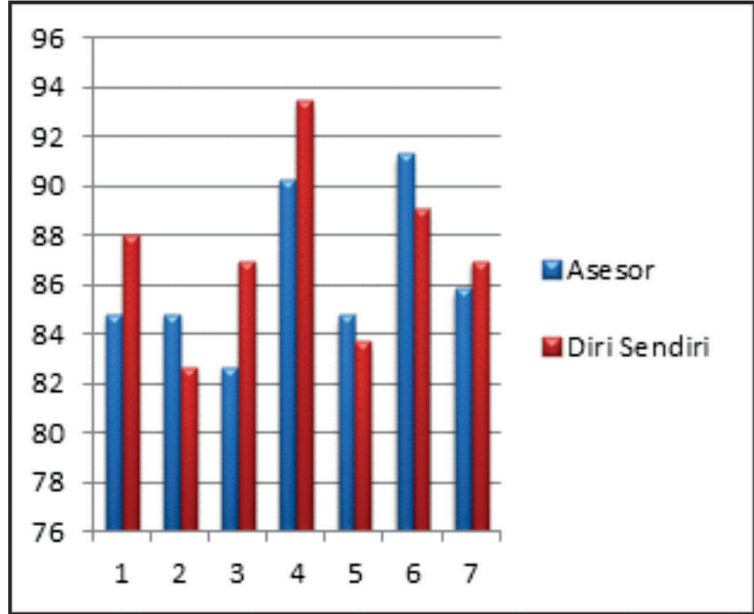

Gambar 4. Rekapitulasi Penilaian Kompetensi Pedagogik Guru IPS SMP Swasta

Jika dilihat dari Tabel 4. maka dapat diketahui bahwa penilaian yang diberikan oleh asesor lebih tinggi dibandingkan dengan penilaian diri sendiri. Hal ini bisa terjadi karena adanya bias dalam penilaian kinerja. Bias ini bisa disebabkan karena penilaian dari asesor akan dikonversikan dalam nilai angka kredit. Kompetensi ini lebih bersinggungan dengan peserta didik, sehingga akan lebih baik apabila peserta didik dilibatkan dalam penilaian kompetensi pedagogik.
Tingkat Ketercapaian Standar Kompetensi Kepribadian Guru IPS SMP

Kompetensi kepribadian terdiri dari 3 indikator dan 18 pernyataan. Berikut ini adalah tabel rekapitulasi penilaian kompetensi kepribadian guru IPS SMP di Kabupaten Kebumen:

Tabel 5. Rekapitulasi Penilaian Kompetensi Kepribadian Guru IPS SMP

\begin{tabular}{|c|c|c|c|c|c|}
\hline \multirow{2}{*}{\multicolumn{2}{|c|}{$\begin{array}{c}\text { Indikator } \\
\text { Asesor }\end{array}$}} & \multicolumn{2}{|c|}{$\begin{array}{c}\text { SMP Negeri } \\
(\%)\end{array}$} & \multicolumn{2}{|c|}{$\begin{array}{c}\text { SMP Swasta } \\
(\%)\end{array}$} \\
\hline & & $\begin{array}{l}\text { Diri } \\
\text { Sen- } \\
\text { diri }\end{array}$ & $\begin{array}{l}\text { Ase- } \\
\text { sor }\end{array}$ & $\begin{array}{c}\text { Diri } \\
\text { Sen- } \\
\text { diri }\end{array}$ & \\
\hline 1 & $\begin{array}{l}\text { Bertindak } \\
\text { sesuai } \\
\text { dengan } \\
\text { norma } \\
\text { agama, } \\
\text { hukum, } \\
\text { sosial, dan } \\
\text { kebuda-yaan } \\
\text { nasional }\end{array}$ & 97,30 & 96,17 & 90,22 & 97,83 \\
\hline 2 & $\begin{array}{l}\text { Menun- } \\
\text { jukkan } \\
\text { pribadi yang } \\
\text { dewasa dan } \\
\text { teladan }\end{array}$ & 94,60 & 91,44 & 91,30 & 97,83 \\
\hline 3 & $\begin{array}{l}\text { Etos kerja, } \\
\text { tanggung } \\
\text { jawab yang } \\
\text { tinggi, rasa } \\
\text { bangga } \\
\text { menjadi } \\
\text { guru }\end{array}$ & 92,34 & 87,61 & 88,04 & 92,39 \\
\hline & $\begin{array}{l}\text { Kompetensi } \\
\text { Kepribadian }\end{array}$ & 94,74 & 91,74 & 89,86 & 96,01 \\
\hline
\end{tabular}

Sumber: data responden yang diukur

Berdasarkan Tabel 5. dapat diketahui bahwa berdasarkan penilaian dari asesor untuk kompetensi kepribadian guru IPS SMP Negeri sebesar 94,74\% dan SMP Swasta sebesar $89,86 \%$ dengan kategori masing-masing amat baik dan baik, sedangkan berdasarkan penilaian diri sendiri SMP Negeri sebesar 91,74\% dan SMP Swasta sebesar 96,01\% dengan kategori masing-masing amat baik. Jika dirata-rata, maka 
hasilnya adalah sebesar 93,09\% dan termasuk dalam kategori amat baik. Hal ini berarti bahwa kinerja guru IPS SMP di Kabupaten Kebumen dilihat dari kompetensi kepribadian sudah sesuai dengan Permendiknas No. 16 Tahun 2007 tentang Standar Kualifikasi Akademik dan Kompetensi Guru. Data diatas dapat digambarkan dengan diagram batang sebagai berikut:

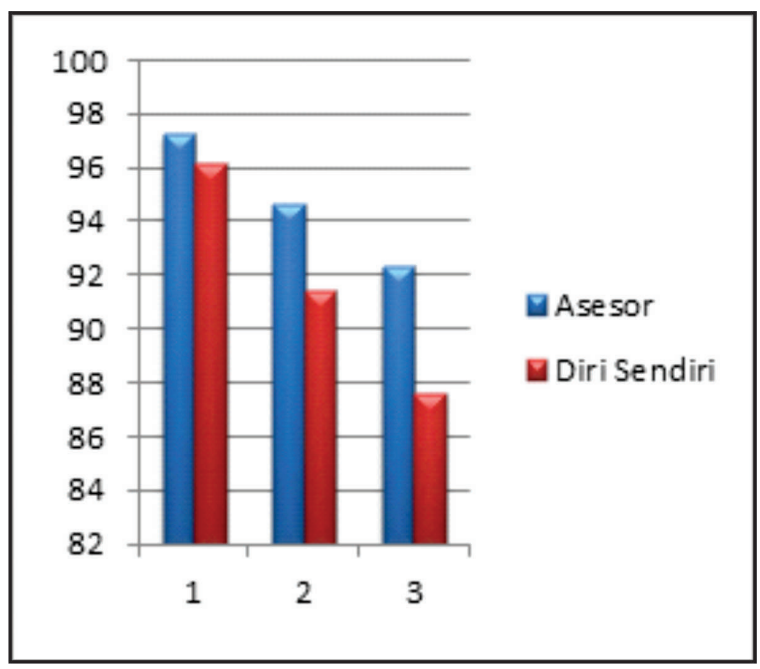

Gambar 5. Rekapitulasi Penilaian Kompetensi Kepribadian Guru IPS SMP Negeri

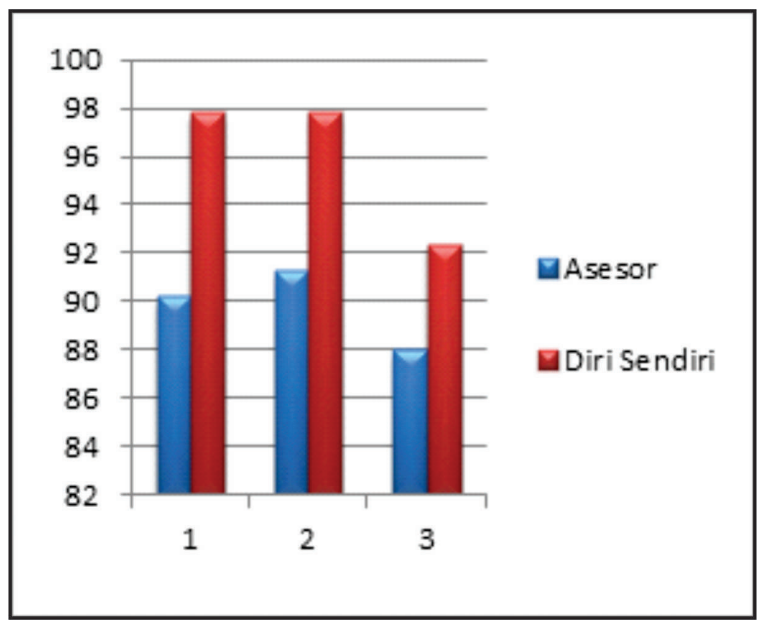

Gambar 6. Rekapitulasi Penilaian Kompetensi Kepribadian Guru IPS SMP Swasta

Jika dilihat dari Tabel 5. maka dapat diketahui bahwa penilaian yang diberikan oleh asesor lebih tinggi dibandingkan dengan penilaian diri sendiri. Hal ini bisa terjadi karena adanya bias dalam penilaian kinerja. Bias ini bisa disebabkan karena penilaian dari asesor akan dikonversikan dalam nilai angka kredit.
Tingkat Ketercapaian Standar Kompetensi Sosial Guru IPS SMP

Kompetensi sosial terdiri dari 2 indikator dan 6 pernyataan. Berikut ini adalah tabel rekapitulasi penilaian kompetensi sosial guru IPS SMP di Kabupaten Kebumen:

Tabel 6. Rekapitulasi Penilaian Kompetensi Sosial Guru IPS SMP

\begin{tabular}{|c|c|c|c|c|c|}
\hline \multirow{2}{*}{\multicolumn{2}{|c|}{$\begin{array}{l}\text { Indikator } \\
\text { Asesor }\end{array}$}} & \multicolumn{2}{|c|}{$\begin{array}{c}\text { SMP Negeri } \\
(\%)\end{array}$} & \multicolumn{2}{|c|}{$\begin{array}{c}\text { SMP Swasta } \\
(\%)\end{array}$} \\
\hline & & $\begin{array}{r}\text { Diri } \\
\text { Sen- } \\
\text { diri } \\
\end{array}$ & $\begin{array}{l}\text { Ase- } \\
\text { sor }\end{array}$ & $\begin{array}{c}\text { Diri } \\
\text { Sen- } \\
\text { diri } \\
\end{array}$ & \\
\hline 1 & $\begin{array}{c}\text { Bersikap } \\
\text { inklusif, } \\
\text { bertindak } \\
\text { objektif, } \\
\text { serta tidak } \\
\text { diskrimina- } \\
\text { tif }\end{array}$ & 93,02 & 91,44 & 91,30 & 97,83 \\
\hline 2 & $\begin{array}{l}\text { Komunika- } \\
\text { si dengan } \\
\text { sesama } \\
\text { guru, } \\
\text { tenaga } \\
\text { kependi- } \\
\text { dikan, } \\
\text { orang tua, } \\
\text { peserta } \\
\text { didik, dan } \\
\text { masyarakat }\end{array}$ & 86,49 & 87,16 & 76,09 & 85,87 \\
\hline & $\begin{array}{l}\text { Kompetensi } \\
\text { Sosial }\end{array}$ & 89,75 & 89,30 & 83,70 & 91,85 \\
\hline
\end{tabular}

Sumber: data responden yang diukur

Berdasarkan Tabel 6. dapat diketahui bahwa berdasarkan penilaian dari asesor untuk kompetensi sosial guru IPS SMP Negeri sebesar $89,75 \%$ dan SMP Swasta sebesar 83,70\% dengan kategori masing-masing baik, sedangkan berdasarkan penilaian diri sendiri SMP Negeri sebesar 89,30\% dan SMP Swasta sebesar 91,85\% dengan kategori masing-masing baik dan amat baik. Jika dirata-rata, maka hasilnya adalah sebesar $88,65 \%$ dan termasuk dalam kategori baik. Hal ini berarti bahwa kinerja guru IPS SMP di Kabupaten Kebumen dilihat dari kompetensi sosial sudah sesuai dengan Permendiknas No. 
16 Tahun 2007 tentang Standar Kualifikasi Akademik dan Kompetensi Guru. Data diatas dapat digambarkan dengan diagram batang sebagai berikut:

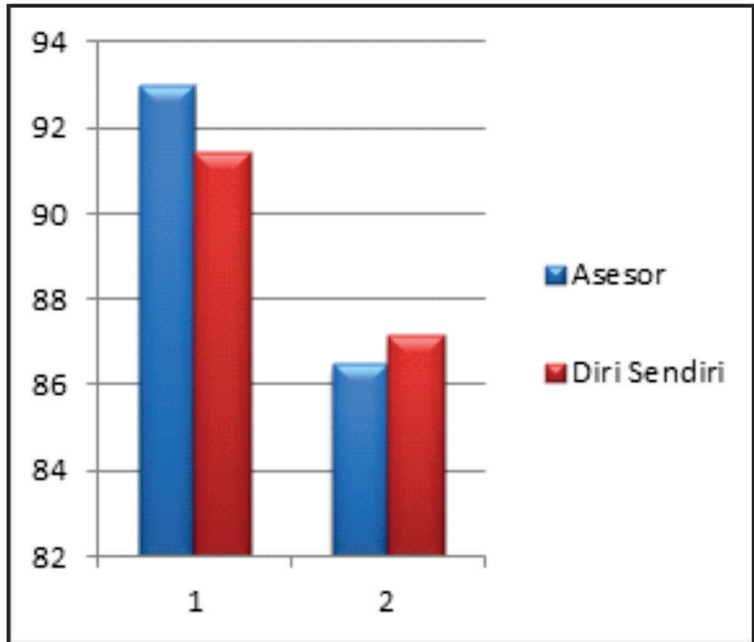

Gambar 7. Rekapitulasi Penilaian Kompetensi Sosial Guru IPS SMP Negeri

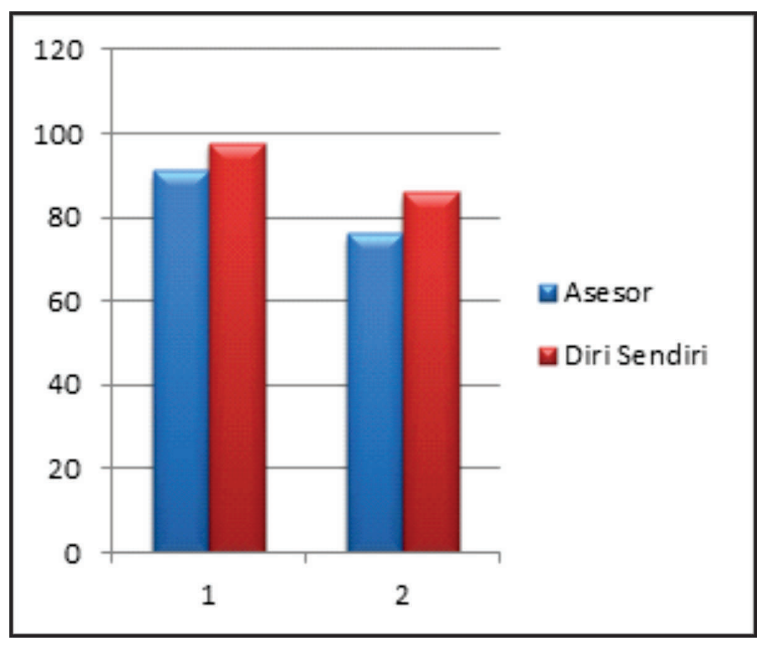

Gambar 8. Rekapitulasi Penilaian Kompetensi

Sosial Guru IPS SMP Swasta

Jika dilihat dari Tabel 6. maka dapat diketahui bahwa penilaian diri sendiri cenderung lebih tinggi jika dibandingkan dengan penilaian yang diberikan oleh asesor. Hal ini bisa terjadi karena adanya bias dalam penilaian kinerja. Bias ini bisa disebabkan karena kompetensi sosial, tidak hanya berkaitan dengan guru ketika di sekolah tapi juga ketika guru berada di luar sekolah. Tidak semua asesor bisa mengamati sikap dan tindakan guru ketika di luar sekolah.
Tingkat Ketercapaian Standar Kompetensi Profesional Guru IPS SMP

Kompetensi profesional terdiri dari 2 indikator dan 9 pernyataan. Berikutini adalah tabel rekapitulasi penilaian kompetensi profesional guru IPS SMP di Kabupaten Kebumen:

Tabel 7. Rekapitulasi Penilaian Kompetensi Profesional Guru IPS SMP

\begin{tabular}{|c|c|c|c|c|c|}
\hline \multirow{2}{*}{\multicolumn{2}{|c|}{$\begin{array}{l}\text { Indikator } \\
\text { Asesor }\end{array}$}} & \multicolumn{2}{|c|}{$\begin{array}{c}\text { SMP Negeri } \\
(\%)\end{array}$} & \multicolumn{2}{|c|}{$\begin{array}{c}\text { SMP Swasta } \\
(\%)\end{array}$} \\
\hline & & $\begin{array}{l}\text { Diri } \\
\text { Sen- } \\
\text { diri }\end{array}$ & $\begin{array}{c}\text { Ase- } \\
\text { sor }\end{array}$ & $\begin{array}{l}\text { Diri } \\
\text { Sen- } \\
\text { diri }\end{array}$ & \\
\hline 1 & \begin{tabular}{|l} 
Penguasaan \\
materi, \\
struktur, \\
konsep, dan \\
pola pikir \\
keilmuan \\
yang mendu- \\
kung mata \\
pelajaran \\
yang diampu
\end{tabular} & 86,04 & 87,39 & 67,39 & 82,61 \\
\hline 2 & $\begin{array}{l}\text { Mengem- } \\
\text { bangkan } \\
\text { keprofesio- } \\
\text { nalan } \\
\text { melalui } \\
\text { tindakan } \\
\text { yang } \\
\text { reflektif }\end{array}$ & 81,98 & 79,73 & 78,26 & 72,83 \\
\hline & $\begin{array}{l}\text { Kompetensi } \\
\text { Profesional }\end{array}$ & 84,01 & 83,56 & 72,83 & 77,72 \\
\hline
\end{tabular}

Sumber: data responden yang diukur

Berdasarkan Tabel 7. dapat diketahui bahwa berdasarkan penilaian dari asesor untuk kompetensi profesional guru IPS SMP Negeri sebesar 84,01\% dan SMP Swasta sebesar 72,83\% dengan kategori masing-masing baik dan cukup, sedangkan berdasarkan penilaian diri sendiri SMP Negeri sebesar 83,56\% dan SMP Swasta sebesar 77,72\% dengan kategori masing-masing baik. Jika dirata-rata, maka hasilnya adalah sebesar 79,53\% dan termasuk dalam kategori baik. Hal ini berarti bahwa kinerja guru IPS SMP di Kabupaten Kebumen dilihat dari kompetensi profesional sudah sesuai dengan Permendiknas No. 16 Tahun 2007 tentang Standar Kualifikasi 
Akademik dan Kompetensi Guru. Data diatas dapat digambarkan dengan diagram batang sebagai berikut:

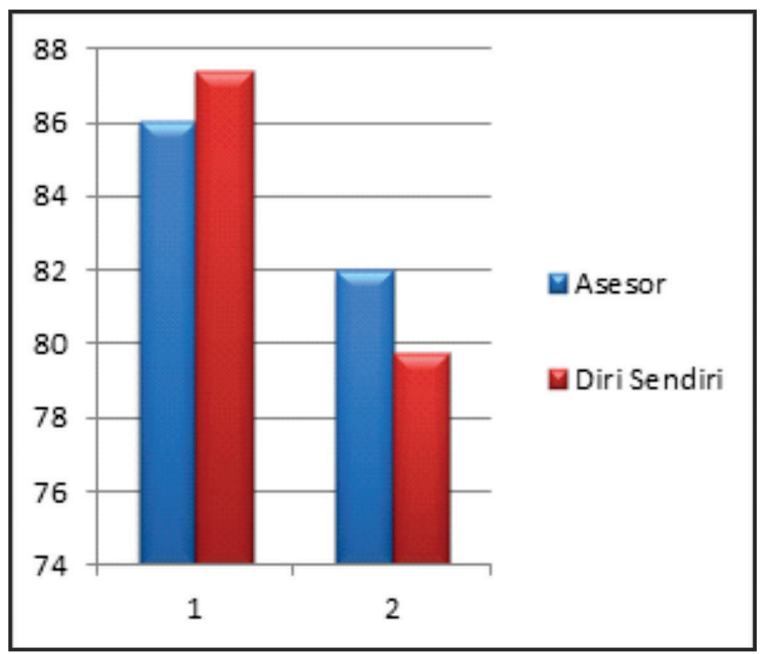

Gambar 9. Rekapitulasi Penilaian Kompetensi Profesional Guru IPS SMP Negeri

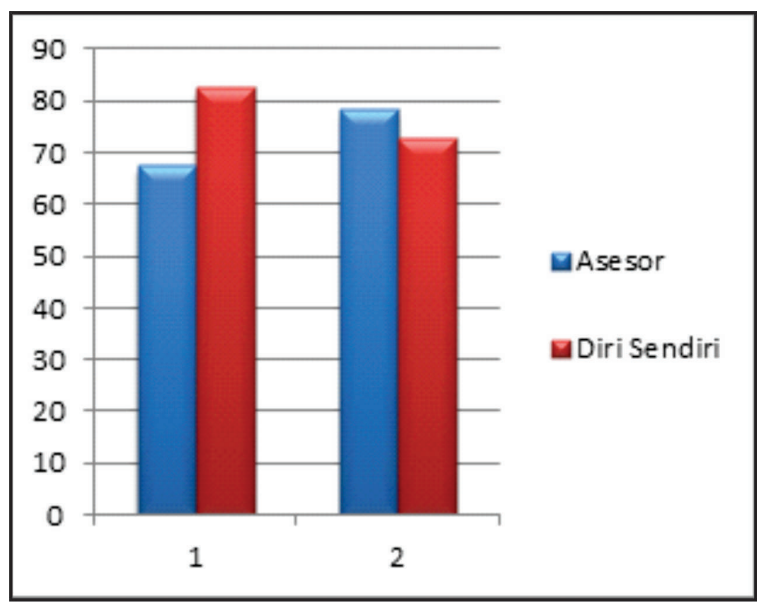

Gambar 10. Rekapitulasi Penilaian Kompetensi Profesional Guru IPS SMP Swasta

Jika dilihat dari Tabel 70. maka dapat diketahui bahwa pada indikator penguasaan materi, struktur, konsep, dan pola pikir keilmuan yang mendukung mata pelajaran yang diampu baik pada SMP Negeri maupun SMP Swasta penilaian diri sendiri cenderung lebih tinggi dari pada penilaian dari asesor. Hal ini bisa terjadi karena asesor tidak memiliki latar belakang pendidikan yang sama dengan guru IPS, sehingga mereka tidak begitu memahami tentang materi IPS.

Pada indikator mengembangkan keprofesionalan melalui tindakan yang reflektif baik pada SMP Negeri maupun SMP Swasta penilaian diri sendiri cenderung lebih rendah dari pada penilaian dari asesor. Hal ini dikarenakan banyak guru IPS yang belum membuat jurnal, karya ilmiah, PTK dan penelitian lainnya. Selain itu, terdapat beberapa guru IPS yang belum memiliki kompetensi TIK yang mumpuni. Sebenarnya pada beberapa sekolah sudah diadakan pelatihan TIK, hanya saja karena sebagian besar guru IPS sudah berumur, maka menyebabkan mereka mengalami banyak kendala dan kesulitan dalam mempelajari TIK.

\section{Simpulan,Implikasi, dan Saran}

\section{Simpulan}

Berdasarkan hasil penelitian dan pembahasan, maka dapat disimpulkan bahwa: (1) kompetensipedagogikguruIPS SMPdi Kabupaten Kebumen dalam kategori baik dengan persentase sebesar $88,00 \%$; (2) kompetensi kepribadian guru IPS SMP di Kabupaten Kebumen dalam kategori amat baik dengan persentase sebesar 93,09\%; (3) kompetensi sosial guru IPS SMP di Kabupaten Kebumen dalam kategori baik dengan persentase sebesar 88,65\%; dan (4) kompetensi profesional guru IPS SMP di Kabupaten Kebumen dalam kategori baik dengan persentase sebesar 79,53\%. Hal ini berarti bahwa kinerja guru IPS SMP di Kabupaten Kebumen berdasarkan kompetensi guru sudah sesuai dengan Permendiknas Nomor 16 Tahun 2007 tentang Standar Kualifikasi Akademik dan Kompetensi Guru.

Implikasi

Implikasi dari penelitian ini adalah (1) jika kompetensi pedagogik guru IPS dalam kategori baik, maka mereka akan memberikan bimbingan kepada guru IPS lain yang memiliki kategori cukup dan kurang; (2) jika kompetensi kepribadian guru IPS dalam kategori amat baik, maka peserta didik akan menjadikan guru IPS sebagai contoh dan panutan; (3) jika kompetensi sosial guru IPS dalam kategori baik, maka akan tercipta hubungan yang baik antara sekolah dengan masyarakat; dan (4) jika kompetensi profesional guru IPS SMP Swasta berdasarkan penilaian dari asesor dalam kategori cukup, maka akan dilakukan pelatihan terkait dengan kompetesi profesional.

Saran

Saran dari penelitian ini adalah (1) untuk meningkatkan kompetensi pedagogik guru, maka 
guru yang sudah memiliki nilai yang amat baik dan baik dapat memberikan bimbingan kepada guru lain yang memiliki nilai cukup dan kurang, serta sekolah dan Dikpora dapat menggiatkan dan memfasilitasi kelompok musyawarah guru seperti KKG, MGMP, dan lain-lain; (2) agar guru IPS tetap bisa dijadikan contoh dan panutan bagi peserta didik, sebaiknya guru IPS tetap mempertahankan kompetensi kepribadian guru dalam kategori amat baik. Oleh karena itu, sebaiknya Dikpora dan kepala sekolah selalu memberikan bimbingan dan pengarahan secara kontinue, misalnya dengan memberikan bimbingan rohani kepada guru setiap bulan; (3) untuk tetap menjaga hubungan yang baik antara sekolah dengan masyarakat, maka sebaiknya guru IPS memiliki kompetensi sosial yang baik; dan (4) beberapa guru IPS SMP di Kabupaten Kebumen belum memiliki kemampuan TIK yang mumpuni dan belum melakukan penelitian tindakan kelas. Oleh karena itu, untuk meningkatkan kompetensi profesional guru perlu diadakan pelatihan komputer yang rutin dan berkelanjutan. Selain itu, perlu adanya diklat tentang penelitian tindakan kelas mulai dari penyusunan proposal, pelaksanaan penelitian termasuk cara mengumpulkan dan mengolah data, serta penulisan hasil penelitian.

\section{Daftar Pustaka}

Harriyanti, Rini. (2000). Kontribusi iklim kerjasama dan pelaksanaan supervisi terhadap kinerja guru SMUN kecematan karimun kabupaten kepulauan Riau. Jurnal Pasca Sarjana Universitas Negeri Padang1 (1). 44-53.

Jones, J., Mazda J. \& Sue Lard. (2006). Developing effective teacher performance. London: Paul Chapman Publishing.

Nawawi, Hadari. (2006). Evaluasi dan manajemen kinerja di lingkungan perusahaan dan industri. Yogyakarta: Gajah Mada University Press.
Nolan, James F. \& Hoover, Linda A. (2011). Teacher supervision and evaluation: theory into practice. Hoboken: John Wiley $\&$ Sons, Inc.

Nursa'ban, M., Suparmini, \& Sriadi Setyowati. (2012). Evaluasi kompetensi pedagogik guru geografi SMA di Kabupaten Bantul. SOCIA, Vol. 1. Retrieved from http:// journal.uny.ac.id/index.php/hsipi/article/ view/3085.

Hamalik, Oemar. (2008). Proses belajar mengajar. Jakarta: Bumi Aksara.

Parkes, Kelly A.. (2010). Performance assessment: lessons from performers (jurnal). International Journal of Teaching and Learning in Higher Education, Volume 22.

Permendiknas Nomor 16 Tahun 2007 tentang Standar Kualifikasi Akademik dan Kompetensi Guru.

Priansa, Donni J.. (2014). Kinerja dan profesionalisme guru. Bandung: Alfabeta.

Priatna, Nanang \& Tito Sukamto. (2013). Pengambangan profesi guru. Bandung: Remaja Rosdakarya.

Rachmawati, Tutik \& Daryanto. (2013). Penilaian kinerja profesi guru dan angka kreditnya. Jogjakarta: Gava Media.

Suryarahman, E., \& Hastuti, H. (2014). Kinerja guru ips smp bersertifikasi profesi berdasarkan standar kompetensi guru di kabupaten lombok utara. Harmoni Sosial: Jurnal Pendidikan IPS, 1(2). Retrieved from http://journal.uny.ac.id/index.php/ hsjpi/article/view/2435

Widoyoko, Eko P.. (2012). Teknik penyusunan instrumen penelitian. Yogyakarta: Pustaka Pelajar.

Yamin, Martinis \& Maisah. (2010). Standarisasi kinerja guru. Jakarta: Gaung Persada Press. 